\title{
Relation between duration of smoking cessation and bronchial inflammation in COPD
}

\section{T S Lapperre, D S Postma, M M E Gosman, J B Snoeck-Stroband, N H T ten Hacken, P S Hiemstra, W Timens, P J Sterk, T Mauad, on behalf of the GLUCOLD Study Group*}

Thorax 2006;61:115-121. doi: 10.1136/thx.2005.040519

See end of article for authors' affiliations

Correspondence to: Dr T S Lapperre, Lung Function Laboratory, Department of Pulmonology, Leiden University Medical Centre, P O Box 9600,2300 RC Leiden, The Netherlands; t.s.lapperre@lumc.nl

Received 20February 2005 Accepted 17 July 2005

Published Online First

2 September 2005
Background: Chronic obstructive pulmonary disease (COPD) is associated with airway inflammation. Although smoking cessation improves symptoms and the decline in lung function in COPD, it is unknown whether bronchial inflammation in patients with established COPD varies with the duration of smoking cessation.

Methods: 114 patients (99 men) with COPD of mean (SD) age 62 (8) years, a median (IQR) smoking history of $42(31-55)$ pack years, no inhaled or oral corticosteroids, all current or ex-smokers ( $n=42$, quit $>1$ month, median cessation duration 3.5 years), post-bronchodilator $\mathrm{FEV}_{1} 63$ (9)\% predicted, and $\mathrm{FEV}_{1}$ /IVC 48 (9)\% were studied cross sectionally. The numbers of subepithelial T lymphocytes (CD3, CD4, CD8), neutrophils, macrophages, eosinophils, mast cells, and plasma cells were measured in bronchial biopsy specimens (median (IQR)/0.1 $\mathrm{mm}^{2}$ ) using fully automated image analysis.

Results: Ex-smokers with COPD had higher $\mathrm{CD} 3+, \mathrm{CD} 4+$, and plasma cell numbers than current smokers with COPD (149 (88-225) v 108 (61-164), $p=0.036$; 58 (32-90) v 40 (25-66), p=0.023; and 9.0 $(5.5-20) \vee 7.5(3.1-14), p=0.044$, respectively), but no difference in other inflammatory cells. Short term ex-smokers $(<3.5$ years) had higher CD4+ and CD8+ cell numbers than current smokers $(p=0.017$, $p=0.023$; respectively). Conversely, long term ex-smokers (quit $\geqslant 3.5$ years) had lower CD8+ cell numbers than short term ex-smokers $(p=0.009)$, lower $C D 8 / C D 3$ ratios than both current smokers and short-term ex-smokers $(p=0.012, p=0.003$; respectively), and higher plasma cell numbers than current smokers $(p=0.003)$

Conclusions: With longer duration of smoking cessation, CD8 cell numbers decrease and plasma cell numbers increase. This indicates that bronchial $T$ lymphocyte and plasma cell counts, but not other inflammatory cells, are related to duration of smoking cessation in patients with COPD.
C hronic obstructive pulmonary disease (COPD) is characterised by progressive airflow limitation and abnormal inflammatory responses in the airways. ${ }^{1}$ Persistent smoking-induced inflammation is thought to play an important role in the pathogenesis of COPD. It is characterised by influx of neutrophils into the airway lumen and increased macrophage and $\mathrm{T}$ lymphocyte numbers in the airway wall. ${ }^{2}$ In particular, bronchial CD8+ T lymphocytes appear to be associated with the severity of the disease. ${ }^{4}$ Moreover, sputum CD8+ cells of patients with COPD have increased cytotoxic activity ${ }^{5}$ which may contribute to the tissue damage which occurs in these patients. It has recently been shown that $\mathrm{B}$ cell numbers in the small airways of patients with COPD are also increased. ${ }^{3}$ Plasma cells (terminally differentiated effector B cells) are the cellular source of mucosal immunoglobulin production and consequently play a central role in host defence against infection. However, there are limited data on their role in COPD, and their presence in the lung has not been investigated in relation to smoking status.

Smoking cessation is the only intervention able to reduce the progression of COPD. ${ }^{6}$ Moreover, patients who quit smoking experience less respiratory symptoms and hyperresponsiveness than those who continue to smoke. ${ }^{78}$ The largest improvements in lung function and symptoms occur within the first year after cessation. It is not yet clear whether these beneficial effects are accompanied by reversal of smoking induced pathology.

At present there is insufficient evidence that smoking cessation reduces inflammation in COPD. Few cross sectional studies have compared smokers and ex-smokers with regard to bronchial inflammation in heterogeneous and relatively small groups of patients without an established diagnosis of COPD. ${ }^{9}$ Most previous studies have been performed in patients with chronic bronchitis. ${ }^{10}{ }^{11}$ In patients with symptoms of chronic cough and expectoration, ex-smokers tend to have lower mast cell numbers in the lamina propria than current smokers, ${ }^{10}$ whereas the number of neutrophils, macrophages, eosinophils, and lymphocytes in bronchial biopsies have been reported to be similar. ${ }^{11}$ Most studies did not take duration of smoking cessation into account when comparing current and ex-smokers. However, it has been shown that this may influence the inflammatory response in small airways. ${ }^{12}$ The available studies may not be representative of COPD since relatively low numbers of patients with airflow limitation were included. It therefore remains to be investigated whether bronchial inflammation varies with current smoking status and the duration of smoking cessation in patients with an established diagnosis of COPD.

In the current study we postulated that bronchial inflammation in patients with established COPD differs between active smokers and patients who stopped smoking, and that this difference is influenced by the duration of smoking cessation. We therefore investigated the number of inflammatory cells (neutrophils, macrophages, eosinophils,

*The GLUCOLD Study Group: Groningen Leiden Universities and Corticosteroids in Obstructive Lung Disease; a full list of members is given in the Appendix to this paper. 
mast cells, T lymphocytes, plasma cells, and granzyme B+ cells as a marker of activated cytotoxic cells) in bronchial biopsy specimens from current and ex-smokers with COPD in a large cross sectional study.

\section{METHODS}

\section{Subjects}

One hundred and fourteen patients with COPD participating in the Groningen Leiden Universities and Corticosteroids in Obstructive Lung Disease (GLUCOLD) study were included in the study. Patient characteristics and methods have been described in detail previously. ${ }^{13}$ In short, all patients had irreversible airflow limitation compatible with GOLD stages 2 and 3 (post-bronchodilator forced expiratory volume in 1 second $\left(\mathrm{FEV}_{1}\right)$ and $\mathrm{FEV}_{1}$ /inspiratory vital capacity (IVC) $<90 \%$ confidence interval (CI) of the predicted value, $\mathrm{FEV}_{1}$ $\geqslant 1.3 \mathrm{l}$ and $>20 \%$ predicted) and at least one of the following symptoms: chronic cough, chronic sputum production, or dyspnoea on exertion. Patients with a history of asthma, $\alpha_{1}$ antitrypsin deficiency, or other active lung disease were not included in the study. Study subjects had not taken a course of oral steroids during the previous 3 months and had not received maintenance treatment with inhaled or oral steroids during the previous 6 months. Patients were allowed to use short acting bronchodilators and were in a stable clinical condition. They were current or ex-smokers (quit smoking for at least 1 month) with a smoking history of at least 10 pack years. A validated questionnaire was used to assess the smoking history. ${ }^{14}$ Those who had quit were asked at what age they stopped in order to calculate the duration of smoking cessation (years).

The medical ethics committees of the Leiden University Medical Center and the Groningen University Medical Center approved the study, and all patients gave their written informed consent.

\section{Study design and lung function}

The study had a cross sectional design and consisted of four visits. Spirometry, reversibility to salbutamol, and carbon monoxide transfer coefficient were measured according to previously described methods in order to characterise the patients. ${ }^{13}$

\section{Bronchoscopy}

Fibreoptic bronchoscopy was performed using a standardised protocol according to recent recommendations. ${ }^{15}$ Smokers were requested to refrain from smoking on the day of the bronchoscopy. Patients were premedicated with $400 \mu \mathrm{g}$ salbutamol intraperitoneally, $20 \mathrm{mg}$ codeine orally, $0.5 \mathrm{mg}$ atropine subcutaneously, and local anaesthesia with lidocaine $(\leqslant 3 \mathrm{mg} / \mathrm{kg})$. During the procedure $100 \%$ oxygen was delivered through a nasal canula $(2 \mathrm{l} / \mathrm{min})$ if required while transcutaneous oxygen was monitored continuously by oximeter with a finger probe. Bronchoscopic examinations were performed by experienced pulmonary physicians using a fibreoptic bronchoscope (18X, outer diameter $6 \mathrm{~mm}$, Pentax Optical Co, Japan) and pairs of cup forceps (Reda, Tuttlingen, Germany). Six macroscopically adequate bronchial biopsy specimens were randomly taken from (sub) segmental carinae in the right or left lower lobe (left and right lobes were alternated per patient, all biopsies from one lung).

\section{Biopsy processing and staining}

Four biopsy specimens were immediately fixed in $4 \%$ neutral buffered formalin for 24 hours, then processed and embedded in paraffin, and two were immediately snap frozen and stored at $-80^{\circ} \mathrm{C}$. Paraffin embedded biopsies were cut in $4 \mu \mathrm{m}$ thick sections and haematoxylin/eosin staining was used for evaluation and selection of the two morphological best biopsies per patient for analysis (without crushing artifacts, large blood clots, or only epithelial scrapings). If required, immunohistochemistry included antigen retrieval. Specific antibodies against $\mathrm{T}$ lymphocytes (CD3, CD4, CD8), macrophages (CD68), neutrophil elastase (NE), mast cell tryptase (AA1), eosinophils (EG2), plasma cells (CD138), and granzyme B were used (table 1). Besides staining the plasma cells, CD138 (syndecan-1) antibody also stains the bronchial epithelium and submucosal glands, ${ }^{16}$ but these structures were not present in the areas of subepithelial cell quantification. All stainings except for CD3 and CD4 were performed using an automatic staining machine (Dako) in two sessions, with one section per patient in each session. In short, the sections were incubated with an optimal dilution of the primary antibodies in $1 \% \mathrm{BSA} / \mathrm{PBS}$ at room temperature for 60 minutes. As a secondary antibody, the horseradish peroxidase conjugated anti-mouse or anti-rabbit EnVision system (DAKO, Glostrup, Denmark) was used with NovaRED (Vector, Burlingame, CA) as the chromagen. The sections were counterstained with Mayer's haematoxylin (Klinipath, Duiven, The Netherlands). For negative controls, the first antibody was omitted from this procedure.

\section{Analysis of bronchial biopsies}

Multiple digital images per coded biopsy section were prepared using a colour camera (Basler Al0lfc-le) and a dedicated software program (RVC Software, Amersfoort, The Netherlands). These images were united into one large image that consisted of the entire biopsy section ( $100 \mu \mathrm{m}=115.7$ pixels). Fully automated inflammatory cell counting procedures were performed according to previously described validated methods. ${ }^{17}$ The number of subepithelial positively staining inflammatory cells was counted within the largest possible area of maximal $125 \mu \mathrm{m}$ deep beneath the basement membrane, per biopsy section, and expressed as the mean number of cells $/ 0.1 \mathrm{~mm}^{2}$ of the two biopsies. Because of very low numbers of granzyme B+ cells, these

Table 1 Antibodies used for immunohistochemistry

\begin{tabular}{llllll}
\hline Antibody & Pretreatment & Species & Dilution & Clone & Origin* \\
\hline CD3 (lymphocyte) & Citrate & Rabbit & $1: 500$ & Polyclonal & Dako \\
CD4 (T helper) & Citrate & Mouse & $1: 300$ & CD4-368 & Novocastra \\
CD8 (T cytotoxic) & Citrate & Mouse & $1: 50$ & CD8-144B & Dako \\
$\begin{array}{l}\text { Neutrophil elastase } \\
\text { (neutrophil) }\end{array}$ & Protease & Mouse & $1: 3200$ & NP57 & Dako \\
CD68 (macrophage) & Citrate & Mouse & $1: 3000$ & KP1 & Dako \\
Tryptase (mast cell) & Citrate & Mouse & $1: 16000$ & AA1 & Dako \\
EG2 (eosinophil) & Trypsin & Mouse & $1: 150$ & EG-2 & Pharmacia \\
CD138 (plasma cell) & EDTA & Mouse & $1: 6400$ & B-B4 & IQ products \\
Granzyme B & Citrate & Mouse & $1: 200$ & CLB-GB7 & CLB/Sanquin \\
\hline
\end{tabular}

*Dako, Glostrup, Denmark; Novocastra, Newcastle upon Tyne, UK; Pharmacia Diagnostics, Uppsala, Sweden; IQ Products, Groningen, The Netherlands; CLB/Sanquin, Amsterdam, The Netherlands. 
Table 2 Characteristics of current smokers and ex-smokers with COPD

\begin{tabular}{|c|c|c|c|c|}
\hline & Current smokers & $\begin{array}{l}\text { Ex-smokers } \\
\text { (combined group) }\end{array}$ & $\begin{array}{l}\text { Ex-smokers } \\
\text { (quit }<3.5 \text { years) }\end{array}$ & $\begin{array}{l}\text { Ex-smokers } \\
\text { (quit } \geqslant 3.5 \text { years) }\end{array}$ \\
\hline $\operatorname{Sex}(M / F, n)$ & $59 / 13$ & $40 / 2^{*}$ & $20 / 1$ & $20 / 1$ \\
\hline Age (years) & $60(8)$ & $64(7)^{*}$ & $61(8)$ & $67(4)^{\star} \dagger$ \\
\hline Pack years (years) & $43(32-56)$ & $37(28-53)$ & $45(29-65)$ & $35(26-41)^{*}$ \\
\hline Duration of smoking cessation (years) & - & $3.5(1-10)$ & $1.0(1.0-2.0)$ & $10(6.5-14.5)$ \\
\hline Smoking duration (years) & $44(8)$ & $41(10)$ & $43(11)$ & 39 (8) \\
\hline $\begin{array}{l}\text { Chronic bronchitis }(\%) \\
\text { Lung function }\end{array}$ & 55.6 & $31.0^{*}$ & $23.8^{*}$ & 38.1 \\
\hline Post-bronchodilator FEV 1 (\% pred) & $63.3(8.3)$ & $62.5(9.6)$ & $62.6(10)$ & $62.5(9.4)$ \\
\hline Post-bronchodilator $\mathrm{FEV}_{1}$ / IVC (\%) & $49.5(8.5)$ & $46.0(8.3)^{*}$ & $45.3(8.6)^{*}$ & $46.7(8.1)$ \\
\hline$\Delta \mathrm{FEV}$ ( $\%$ pred) & $6.9(5.2)$ & $6.8(4.5)$ & $6.9(3.9)$ & $6.8(5.1)$ \\
\hline $\mathrm{KcO}(\%$ pred) & $73.3(25.1)$ & $80.4(25.9)$ & $75.3(24.9)$ & $85.7(26.5)^{*}$ \\
\hline
\end{tabular}

Data are presented as mean (SD) or median (IQR: 25-75th percentile).

Ex-smokers are divided into two groups based on median duration of smoking cessation (3.5 years).

$\mathrm{FEV}_{1}$, forced expiratory volume in 1 second, IVC, inspiratory vital capacity, $\Delta \mathrm{FEV}$, reversibility to salbutamol (change in $\mathrm{FEV}_{1}$ as percentage of predicted), Kco, carbon monoxide transfer coefficient.

${ }^{*} p<0.05$ compared with COPD current smokers $\left(\chi^{2}\right.$ tests for sex differences, two tailed unpaired $t$ tests for other (log transformed) data).

$t p<0.05$ compared with COPD ex-smokers who quit $<3.5$ years (two tailed unpaired $t$ tests).

were analysed using a semi-quantitative score of the entire biopsy section: 0 (absent staining), 1 ( $1-10$ positive cells), or 2 ( $>10$ positive cells).

\section{Statistical analysis}

Mean values and standard deviations (SD) were computed for normally distributed variables. Cell counts and other variables that did not show a normal distribution were logarithmically transformed (square root in the case of the CD8/CD3 ratio) before statistical analysis and presented as medians with interquartile range (IQR). Normally distributed log transformed cell counts were analysed using parametric tests. EG2 data remained skewed after log transformation and were therefore analysed using non-parametric tests.
Differences between smokers and ex-smokers were explored using $\chi^{2}$ tests, two tailed unpaired $t$ tests, or Mann-Whitney tests. To study the influence of duration of smoking cessation on cell counts, we compared smokers with ex-smokers who quit $<3.5$ years and those who quit $\geqslant 3.5$ years ago, since this was the median duration of smoking cessation, using one way ANOVA (Kruskal-Wallis tests in case of EG2). If these were statistically significant, two tailed unpaired $t$ tests were applied for further exploration of between group differences. Multivariate linear regression analysis was applied to adjust for significant differences in patient characteristics between the groups such as sex, age, pack years, and $\mathrm{FEV}_{\mathrm{l}} / \mathrm{IVC}$. Univariate correlations were evaluated using Spearman and Pearson's correlation coefficients. SPSS 12.0 software (SPSS Inc, Chicago, IL, USA) was used for statistical analysis.
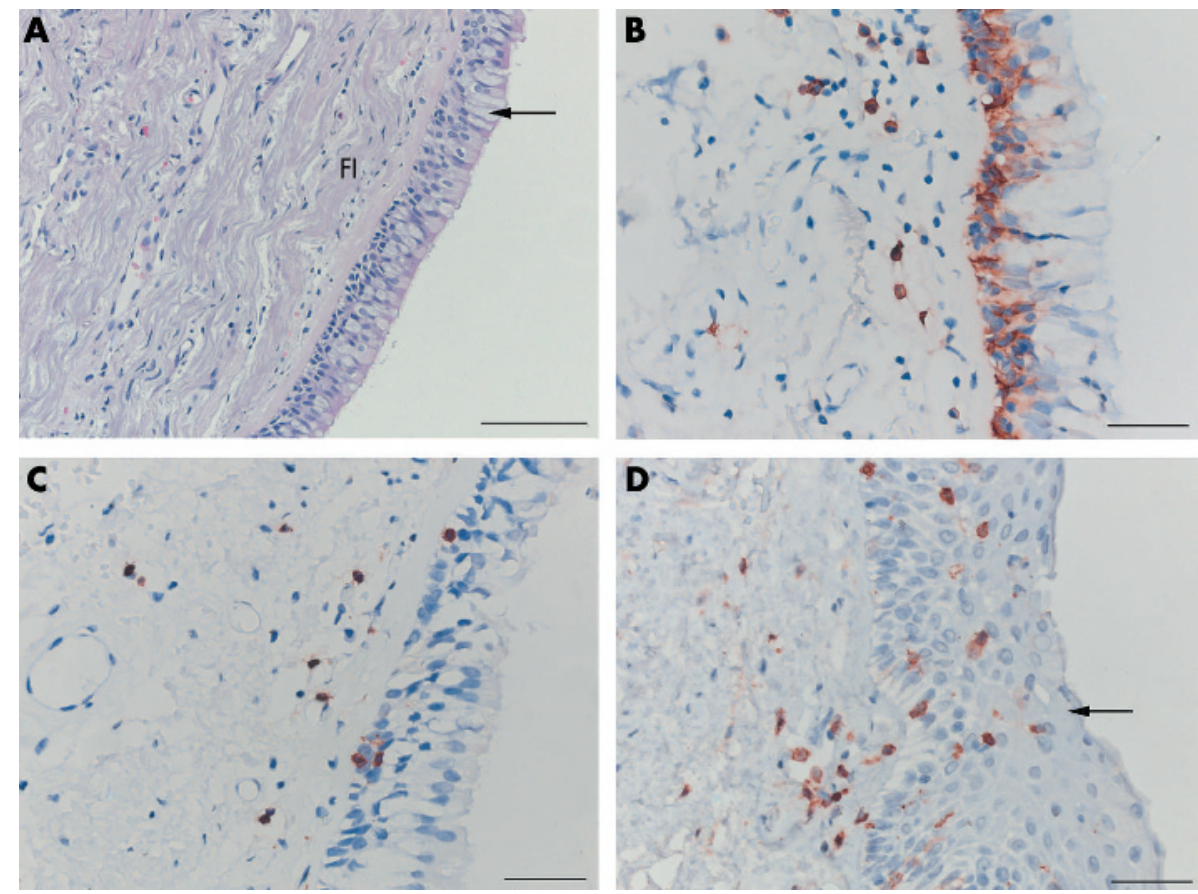

Figure 1 (A) Bronchial biopsy section of a patient with COPD stained with haematoxylin/eosin showing goblet cell hyperplasia of the bronchial epithelium (arrow), fibrosis (FI), and scattered inflammatory cells in the submucosa. (B) Plasma cell staining (CD138). The epithelial layer also stained positive but, for the analysis, only the subepithelial layer was taken into account. (C) CD8+ Tlymphocyte staining. (D) CD4+ T lymphocyte staining also showing squamous cell metaplasia of the epithelium (arrow). Scale bars: (A) $100 \mu \mathrm{m},(B, C$ and D) $20 \mu \mathrm{m}$. 
Table 3 Bronchial inflammatory cell counts of current smokers and ex-smokers with COPD

\begin{tabular}{|c|c|c|c|c|c|}
\hline Cell marker & $\begin{array}{l}\text { Current } \\
\text { smokers }\end{array}$ & $\begin{array}{l}\text { Ex-smokers } \\
\text { (combined group) }\end{array}$ & $\begin{array}{l}\text { Ex-smokers } \\
\text { (quit }<3.5 \text { years) }\end{array}$ & $\begin{array}{l}\text { Ex-smokers } \\
\text { (quit } \geqslant 3.5 \text { years) }\end{array}$ & p valuef \\
\hline CD3 & $108(61-164)$ & $149(88-225)^{*}$ & 137 (93-229) & $170(62-221)$ & 0.097 \\
\hline $\mathrm{CD} 4$ & $40(25-66)$ & $58(32-90)^{*}$ & $64(30-111)^{*}$ & $54(32-75)$ & 0.045 \\
\hline CD8 & $20(11-37)$ & $24(8.8-41)$ & $34(18-54)^{*}$ & $16(7.8-32) \dagger$ & 0.023 \\
\hline CD4/CD8 & $2.0(1.1-3.7)$ & $2.7(1.3-5.0)$ & $2.1(1.2-3.3)$ & $3.1(1.8-6.4)$ & 0.065 \\
\hline CD4/CD3 & $0.4(0.3-0.6)$ & $0.4(0.3-0.8)$ & $0.5(0.3-0.8)$ & $0.4(0.3-0.6)$ & 0.680 \\
\hline $\mathrm{CD} 8 / \mathrm{CD} 3$ & $0.2(0.1-0.3)$ & $0.2(0.1-0.3)$ & $0.3(0.2-0.4)$ & $0.1(0.1-0.2)^{*} \dagger$ & 0.008 \\
\hline NE (neutrophils) & $4.0(2.0-7.8)$ & $4.5(2.0-9.0)$ & $5.0(2.6-9.0)$ & $4.0(1.8-9.8)$ & 0.289 \\
\hline CD68 (macrophages) & $8.5(4.1-12)$ & $11(5.8-18)$ & $11(5.8-17)$ & $8.5(5.8-18)$ & 0.124 \\
\hline EG2 (eosinophils) & $1.3(0.5-3.0)$ & $2.0(0.5-5.5)$ & $1.5(0.5-2.8)$ & $3.5(0.5-11)$ & 0.183 \\
\hline AAl (mast cells) & $28(20-34)$ & $26(18-35)$ & $28(22-36)$ & $24(14-33)$ & 0.303 \\
\hline CD138 (plasma cells) & $7.5(3.1-14)$ & $9.0(5.5-20)^{*}$ & $7.8(4.0-11)$ & $12(7.8-24)^{*}$ & 0.013 \\
\hline
\end{tabular}

Data are presented as median cell number $/ 0.1 \mathrm{~mm}^{2}$ (IQR). Ex-smokers are divided into two groups based on median duration of smoking cessation (3.5 years). ${ }^{*} \mathrm{p}<0.05$ compared with COPD current smokers (two tailed unpaired $t$ tests of log transformed data, square root in case of CD8/CD3).

$\mathrm{tp}<0.05$ compared with COPD ex-smokers who quit $<3.5$ years (two tailed unpaired $t$ tests of log transformed data, square root in case of CD8/CD3). $\neq p$ value from one-way ANOVA (Kruskal-Wallis test in case of EG2) of log transformed data (square root in case of CD8/CD3) between current smokers and exsmokers of $<3.5$ and $\geqslant 3.5$ years with COPD.

\section{RESULTS}

\section{Patient characteristics}

Table 2 shows the characteristics of the 72 smoking and 42 ex-smoking patients included in the study. Patients had moderate to severe COPD, based on a post-bronchodilator $\mathrm{FEV}_{1}$ of $63.0(8.8) \%$ predicted, and a median smoking history of 42 pack years. Median (IQR) duration of smoking cessation in ex-smokers was $3.5(1-10)$ years. The differences in patient characteristics between current and ex-smokers, and between current smokers, short term ex-smokers (quit $<3.5$ years), and long term ex-smokers (quit $\geqslant 3.5$ years) are also shown in table 2 .

\section{Bronchial inflammatory cell counts in smokers and ex- smokers}

All 114 patients underwent bronchoscopy; from one patient (ex-smoker) none of the biopsy specimens taken were adequate for analysis. Figure 1 shows examples of biopsy sections stained with haematoxylin/eosin, CD138, CD8, and CD4. The median analysed surface area of biopsy sections (mucosal area per patient, average of all antibodies in which cells were counted, not corrected for shrinkage) was 0.35 (0.26-0.42) $\mathrm{mm}^{2}$. Ex-smokers had higher CD3+, CD4+, and $\mathrm{CD} 38^{+}$cell numbers than current smokers $(\mathrm{p}=0.036$, $p=0.023, p=0.044$, respectively), but there was no significant difference in other inflammatory cell counts (table 3 ). When differences in sex, age, and $\mathrm{FEV}_{1} / \mathrm{IVC}$ were taken into account in multivariate linear regression analyses, the differences in CD3, CD4, and CD138 remained significant. There were very few granzyme $\mathrm{B}+$ cells in most patients (median 0.5 (IQR 0-1)), and the score was not different between current and ex-smokers with COPD.

\section{Bronchial inflammatory cell counts and duration of smoking cessation}

There were significant differences for CD4+, CD8+, CD8+/ CD3+, and CD138+ cells between current smokers, short term ex-smokers, and long term ex-smokers with COPD (table 3). Short term ex-smokers had higher CD4+ and CD8+ cell numbers than current smokers $(p=0.017, p=0.023$,
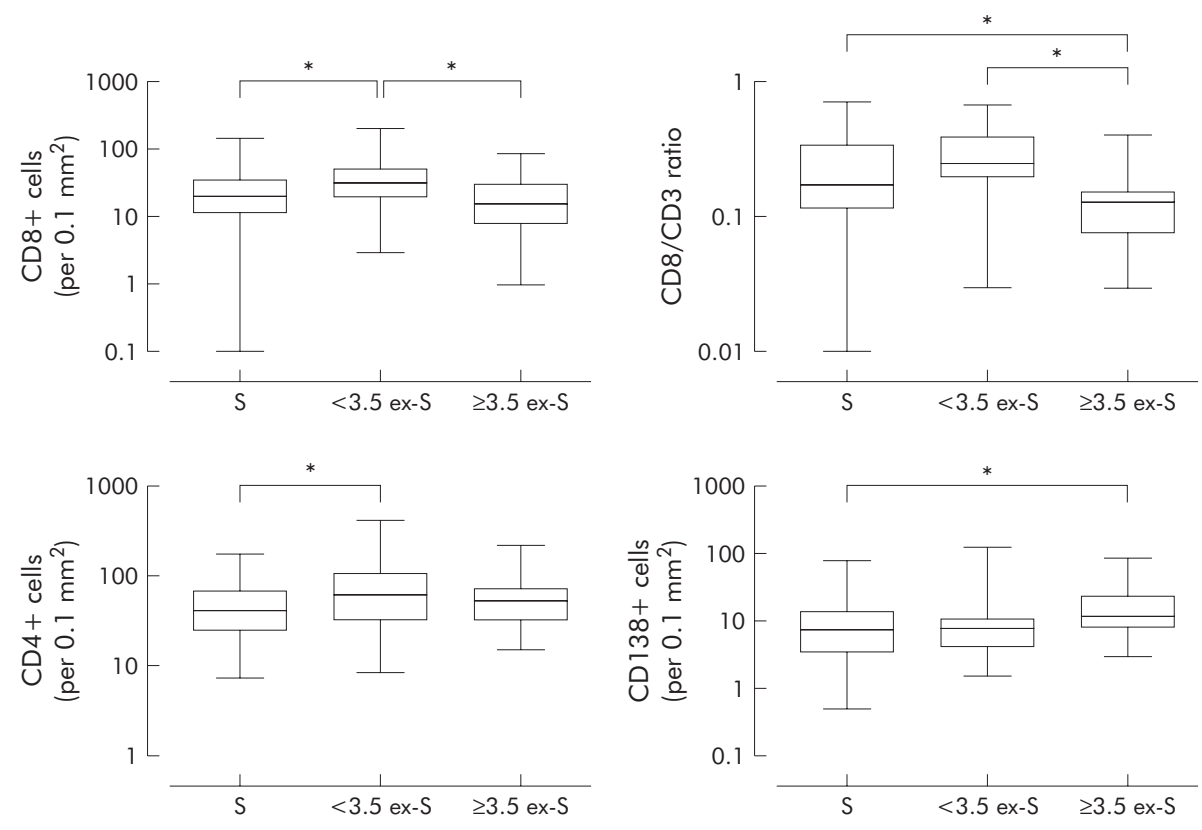

Figure 2 Difference in $C D 4, C D 8, C D 8 / C D 3$, and CD138 cell counts in the lamina propria of smokers (S), ex-smokers who quit $<3.5$ years ago $(<3.5 \mathrm{ex}-\mathrm{S})$, and those who quit $\geqslant 3.5$ years ago $(\geqslant 3.5 \mathrm{ex}-\mathrm{S})$ with COPD. Data are presented as box plots (median, IQR, range) of the number of cells $/ 0.1 \mathrm{~mm}^{2}$ tissue examined or ratios. ${ }^{*} \mathrm{p}<0.05$ (two tailed unpaired $t$ tests of log transformed data (square root in case of CD8/CD3)). 
respectively; table 3, fig 2). These differences persisted after adjustment for differences in post-bronchodilator $\mathrm{FEV}_{1} / \mathrm{IVC}$ between the groups. In contrast, long term ex-smokers had lower CD8+ cell numbers than short term ex-smokers $(p=0.009)$, lower $\mathrm{CD} 8+/ \mathrm{CD} 3+$ ratios than both current smokers $(p=0.012)$ and short term ex-smokers $(p=0.003)$, and higher plasma cell numbers than current smokers $(p=0.003$; table 3 , fig 2$)$, and a trend towards significance versus short term ex-smokers $(p=0.069)$. When adjusting for differences in patient characteristics between the groups, all differences remained significant except for the difference in CD8+ cells between short term and long term quitters. On the other hand, the difference in plasma cells between short term and long term quitters became significant when adjusting for age.

\section{Correlations between bronchial inflammation and smoking behaviour}

When defining current smoking as 0 years stopped, longer duration of smoking cessation was associated with higher numbers of CD3+ cells $\left(r_{\mathrm{s}}=0.221, \mathrm{p}=0.019\right), \mathrm{CD} 4+$ cells $\left(r_{\mathrm{s}}=0.194, \mathrm{p}=0.040\right), \mathrm{CD} 138+$ cells $\left(r_{\mathrm{s}}=0.217, \mathrm{p}=0.021\right)$, and a trend with CD4/CD8 ratios $\left(r_{\mathrm{s}}=0.181, \mathrm{p}=0.056\right)$. Excluding current smokers, longer duration of smoking cessation was associated with lower CD8/CD3 ratios $\left(r_{\mathrm{s}}=-0.395, \mathrm{p}=0.011\right)$ and a trend with higher numbers of CD138+ cells $\left(r_{\mathrm{s}}=0.307, \mathrm{p}=0.051\right)$. The number of pack years smoked was inversely correlated with CDI38+ cells $(R=-0.295, \mathrm{p}=0.002)$.

\section{DISCUSSION}

This study aimed to determine whether the inflammatory cell profile in the bronchial mucosa is different between current smokers and ex-smokers with COPD, and whether this profile is influenced by duration of smoking cessation. Exsmokers had higher numbers of $\mathrm{CD} 3+, \mathrm{CD} 4+$, and plasma cells, whereas the numbers of neutrophils, macrophages, eosinophils, mast cells, and CD8+ cells were not different from current smokers. Interestingly, short term smoking cessation (below the median value of our cohort, that is $<3.5$ years) was associated with higher numbers of CD4+ and CD8+ $\mathrm{T}$ lymphocytes whereas long term smoking cessation ( $\geqslant 3.5$ years) was associated with higher plasma cell numbers and lower CD8/CD3 ratios. These results indicate that the number of bronchial $\mathrm{T}$ lymphocytes and plasma cells in patients with COPD is related to current smoking status and the duration of smoking cessation.

To our knowledge, this is the first study to compare bronchial inflammation in current and ex-smokers within a group of COPD patients and to examine the association with duration of smoking cessation. The observed higher numbers of CD3+ and CD4+ lymphocytes and plasma cells in exsmokers with COPD compared with current smokers with COPD is novel. Consistent with our results, Mullen et al ${ }^{18}$ also reported increased inflammation in the peripheral airways of ex-smokers with mild COPD and mucus hypersecretion compared with current smokers, although the type of cells was not specified. Our observation that large airway inflammation in COPD persists after smoking cessation is in line with previous results in smaller numbers of patients with chronic bronchitis. ${ }^{11}$ Rutgers $e t$ al ${ }^{19}$ also reported ongoing airway inflammation in ex-smokers with COPD compared with healthy ex-smokers but, in contrast to the present study, they did not include current smokers with COPD in the analysis. Our results of an association between T lymphocytes and plasma cells and duration of smoking cessation in COPD are not in line with a study by Wright $e t a l^{20}$ which found no difference in general peripheral airway inflammation between patients with COPD who had quit for $>2$ years,
$<2$ years, and current smokers. However, Lams et al ${ }^{12}$ reported that $\mathrm{CD} 8 / \mathrm{CD} 3$ ratios in peripheral airways are inversely associated with duration of smoking cessation in patients with and without airflow limitation. Taken together, it can now be inferred that, within a group of COPD patients, $\mathrm{T}$ lymphocytes and plasma cell numbers are related to current smoking status and duration of smoking cessation while other inflammatory cells are not.

It seems unlikely that our results are affected by methodological errors. To our knowledge, this is the largest study to date to include bronchial biopsies of 114 well characterised patients with stable COPD of GOLD stages II and III, not using inhaled or oral steroids, and without a clinical diagnosis of asthma. It needs to be emphasised that this was a cross sectional study, and it cannot be ruled out that our ex-smoking group is a selected group of patients who quit smoking because they suffered more from smoking related symptoms and may already have had different cell numbers before quitting. Nevertheless, in the present study ex-smokers had significantly fewer respiratory symptoms than current smokers, while having similar pack years and duration of smoking. In addition, in our analysis we did adjust for clinical differences between the groups. We did not confirm smoking status by laboratory tests and therefore cannot exclude the possibility that some ex-smokers were still smoking. However, this problem is comparable to those in other cross sectional studies in similar subjects. ${ }^{10}{ }^{11} 19 \mathrm{~A}$ fully automated image analysis system was applied for cell counting in airway area sections. ${ }^{17}$ We are aware that counting cells in a two dimensional manner has limitations since it does not take into account the volume of the cell in a given sample; the smallest cells have the least chance of being counted in a single biopsy specimen. Nevertheless, we were able to demonstrate differences in the smallest cells (LY) between the groups. There is still debate in the literature as to whether the theoretical basis of stereology fits well with the limitations of endobronchial biopsies. ${ }^{21}$ However, most of the present data in the literature is based on counting profiles/area which allows comparison between studies, although this is somewhat limited by other methodological factors. Because we observed no granzyme B+ cells in most of the biopsy sections analysed (56\% of all sections) and no differences in a semi-quantitative score between the groups, we did not use digital image analysis for granzyme B+ cell quantification which is a more time consuming procedure. We chose 3.5 years as a cut off time for short term versus long term smoking cessation groups because this was the median duration of smoking cessation, providing equal sample sizes in both groups.

How can we interpret these data? The ongoing inflammation in ex-smokers with COPD suggests the presence of a persistent stimulus that may act independently of cigarette smoking. There are several potential mechanisms-for example, chronic colonisation of the airways with viral and/ or bacterial pathogens in smokers with $\mathrm{COPD}^{22}$ may be responsible for the inflammatory response $e^{23}$ and persist after smoking cessation. In agreement with this, it has been observed that latent adenovirus could persist in ex-smokers with COPD which is associated with enhanced inflammation. ${ }^{25}{ }^{26}$ Smoking may also trigger self-perpetuating inflammatory mechanisms by altering the balance between endogenous pro-inflammatory and anti-inflammatory mechanisms or, as recently suggested, it may induce autoimmune-like phenomena. ${ }^{27}{ }^{28}$ In addition, it was recently observed that apoptosis of airway epithelial cells persists after smoking cessation in patients with $\mathrm{COPD},{ }^{29}$ which may induce persistence of inflammation. It has been suggested that, in smokers without COPD or chronic bronchitis who stopped smoking, lung inflammation is at least partially 
reversible ${ }^{9}$ but persists in patients with COPD. It is therefore possible that the aforementioned stimuli may not persist in ex-smokers without COPD or chronic bronchitis.

The initial increase in CD4+ and CD8+ cells and later increase in plasma cells after smoking cessation might be explained by reversal of immunosuppression. Since both CD4 and CD8 cell numbers returned to similar levels in long term quitters as in current smokers, this reversal of immunosuppression seems transient for lymphocytes but persistent for plasma cells. Smoking cessation may result in reversal of the smoking induced harmful effects on airway epithelial cells ${ }^{30}$ such as a reduction in metaplastic secretory cell numbers in small airways, ${ }^{20}{ }^{31}$ leading to improved lung defence mechanisms. The effector mechanisms of immunity to environmental antigens could therefore be stimulated more efficiently in the absence of smoking, leading to a higher number of immunocompetent cells. Whereas the pro-inflammatory effects of active tobacco smoking have been extensively documented, it may also have selective anti-inflammatory effects as has been described for acute effects of smoking. ${ }^{32}$ Consistent with this and with our results, it was recently observed that cigarette smoke exposure reduced CD4 cell expansion following virus infection. ${ }^{33}$ In addition, tobacco smokers have decreased serum levels of immunoglobulins IgG and IgA, ${ }^{33}{ }^{34}$ suggesting that cigarette smoke modulates the humoral arm of adaptive immunity. Indeed, Soutar et al ${ }^{35}$ described decreased numbers of $\operatorname{IgA}^{+}$cells in patients with fatal chronic bronchitis and suggested that these patients were deficient in plasma cells. These effects of decreased serum immunoglobulin levels appear to be reversible after smoking cessation. ${ }^{36}$ It is possible that smoking cessation leads to an improved capacity to produce immunoglobulins in the airway mucosa of patients with COPD by causing an increase in plasma cell numbers. Loss of these suppressive effects with smoking cessation may also explain our findings of increased numbers of inflammatory cells in ex-smokers, thereby ameliorating lung defence mechanisms.

The decreased CD8/CD3 ratio after quitting for $\geqslant 3.5$ years compared with current smokers and short term quitters, and the lower CD8+ cell numbers in long term compared with short term quitters, suggest that smoking cessation may eventually result in decreased CD8+ cell numbers. Since CD8+ cells have been implicated in the pathogenesis of COPD, a decrease in the number of these cells or their cytotoxic activity may have beneficial effects. However, our findings of very low numbers of cells that stain positive for the CD8 effector molecule granzyme $\mathrm{B}$ in the airways of patients with COPD, in the absence of differences between current and ex-smokers, suggest that these cells may not be cytotoxic. This may be because granzymes are involved in the pathogenesis of emphysema rather than in the conducting airways. ${ }^{37}$ In this respect, it is interesting to note that antigenspecific CD8+ T lymphocytes can persist in the lung long after clearance of a respiratory virus, and that these cells are highly activated and can be stimulated to proliferate, but do not express constitutive effector functions. ${ }^{38}$ In line with these findings, we did observe high numbers of granzyme B positive cells in lung tissue from children with childhood bronchiolitis obliterans, a disease that is thought to result from acute viral bronchiolitis. ${ }^{39}$ In vitro studies may provide additional information by examining more extensively the possible lack of cytotoxicity of CD8+ T lymphocytes in COPD.

What could be the clinical implications of our findings? There is good evidence that smoking cessation results in a decrease in respiratory symptoms, ${ }^{7}$ a lower decline in $\mathrm{FEV}_{1},{ }^{6}$ and a reduction in airway hyperresponsiveness. ${ }^{840}$ Our data suggest that $\mathrm{T}$ lymphocytes and plasma cell numbers change after smoking cessation in COPD while other inflammatory cells persist. Whether these relatively small changes in $\mathrm{T}$ lymphocytes and plasma cell numbers contribute to the clinical benefits of smoking cessation in patients with COPD remains to be established in longitudinal studies. The results suggest that smoking cessation may result in an improvement in local humoral immunity which may result in fewer respiratory infections and exacerbations and thereby a reduced progression of COPD. However, the data also suggest that the clinical benefits of smoking cessation do not simply result from a reduction in inflammatory cells. The mechanisms causing this sustained inflammatory pattern after smoking cessation in COPD remain to be clarified.

In conclusion, this study has shown that ex-smokers with COPD have higher numbers of bronchial CD4+ and plasma cells than current smokers but the numbers of neutrophils, macrophages, and CD8+ cells do not differ between the two groups. T lymphocytes are higher in short term quitters, whereas a longer duration of smoking cessation is associated with lower $\mathrm{CD} 8 / \mathrm{CD} 3$ ratios and higher numbers of plasma cells. This suggests that changes in T lymphocyte and plasma cell numbers may contribute to the clinical benefits of smoking cessation in COPD.

\section{ACKNOWLEDGEMENTS}

The authors thank the patients for their cooperation in the study.

\section{Authors' affiliations}

T S Lapperre, P S Hiemstra, P J Sterk, T Mauad, Department of

Pulmonology, Leiden University Medical Centre, Leiden, The Netherlands J B Snoeck-Stroband, Department of General Practice, Leiden University Medical Centre, Leiden, The Netherlands

T Mauad, Department of Pathology, University of Sao Paulo, Sao Paulo, Brazil

D S Postma, M M E Gosman, N H T ten Hacken, Department of

Pulmonology, Groningen University Medical Centre, Groningen, The Netherlands

W Timens, Department of Pathology, Groningen University Medical Centre, Groningen, The Netherlands

The study was supported by the Netherlands Organization for Scientific Research (NWO), the Netherlands Asthma Foundation (NAF), GlaxoSmithKline (NL), Leiden University Medical Center (LUMC), and Groningen University Medical Center (GUMC).

PS and PH have received, as members of the Department of Pulmonology of the Leiden University Medical Centre, a grant from GSK (UK and NL) as part of the sponsorship of this GLUCOLD study. The other authors declare no competing interests.

\section{APPENDIX}

Members of the GLUCOLD Study Group: H F Kauffman, D de Reus, Department of Allergology; H M Boezen, D F Jansen, J Vonk, Department of Epidemiology and Statistics; M D W Barentsen, W Timens, M Zeinstra-Smit, Department of Pathology; A J Luteijn, T van der Molen, G ter Veen, Department of General Practice; M M E Gosman, N H T ten Hacken, H A M Kerstjens, M S van Maaren, D S Postma, C A Veltman, A Verbokkem, I Verhage, H K Vink-Kloosters, Department of Pulmonology; Groningen University Medical Center, Groningen, The Netherlands; J B Snoeck-Stroband, H Thiadens, Department. of General Practice; J K Sont, Department of Medical Decision Making; I Bajema, Department of Pathology; J Gast-Strookman, P S Hiemstra, K Janssen, T S Lapperre, K F Rabe, A van Schadewijk, J SmitBakker, P J Sterk, J Stolk, A C J A Tiré, H van der Veen, M M E Wijffels and L N A Willems, Department of Pulmonology; Leiden University Medical Center, Leiden, The Netherlands; T Mauad, University of Sao Paulo, Sao Paulo, Brazil.

\section{REFERENCES}

1 Global Initiative for Chronic Obstructive Lung Disease. Global strategy for the diagnosis, management and prevention of chronic obstructive pulmonary 
disease, NHLBI/WHO Workshop Report, 2004.Available at: www.goldcopd.com.

2 Saetta M, Turato $G$, Maestrelli $P$, et al. Cellular and structural bases of chronic obstructive pulmonary disease. Am J Respir Crit Care Med 2001;163:1304-9.

3 Hogg JC, Chu F, Utokaparch S, et al. The nature of small-airway obstruction in chronic obstructive pulmonary disease. N Engl J Med 2004;350:2645-53.

4 O'Shaughnessy TC, Ansari TW, Barnes NC, et al. Inflammation in bronchial biopsies of subjects with chronic bronchitis: inverse relationship of $C D 8^{+} T$ lymphocytes with $\mathrm{FEV}_{1}$. Am J Respir Crit Care Med 1997; 155:852-7.

5 Chrysofakis G, Tzanakis N, Kyriakoy D, et al. Perforin expression and cytotoxic activity of sputum $\mathrm{CD} 8^{+}$lymphocytes in patients with COPD. Chest 2004:125:71-6.

6 Anthonisen NR, Connett JE, Kiley JP, et al. Effects of smoking intervention and the use of an inhaled anticholinergic bronchodilator on the rate of decline of $\mathrm{FEV}_{1}$. The Lung Health Study. JAMA 1994;272:1497-505.

7 Kanner RE, Connett JE, Williams DE, et al. Effects of randomized assignment to a smoking cessation intervention and changes in smoking habits on respiratory symptoms in smokers with early chronic obstructive pulmonary disease: the Lung Health Study. Am J Med 1999;106:410-6.

8 Wise RA, Kanner RE, Lindgren $\mathrm{P}$, et al. The effect of smoking intervention and an inhaled bronchodilator on airways reactivity in COPD: The Lung Health Study. Chest 2003;124:449-58.

9 Willemse BW, Postma DS, Timens W, et al. The impact of smoking cessation on respiratory symptoms, lung function, airway hyperresponsiveness and inflammation. Eur Respir J 2004;23:464-76.

10 Pesci A, Rossi GA, Bertorelli G, et al. Mast cells in the airway lumen and bronchial mucosa of patients with chronic bronchitis. Am J Respir Crit Care Med 1994;149:1311-6.

11 Turato G, Di Stefano A, Maestrelli P, et al. Effect of smoking cessation on airway inflammation in chronic bronchitis. Am J Respir Crit Care Med 1995; 152:1262-7.

12 Lams BE, Sousa AR, Rees PJ, et al. Immunopathology of the small-airway submucosa in smokers with and without chronic obstructive pulmonary disease. Am J Respir Crit Care Med 1998;158:1518-23.

13 Lapperre TS, Snoeck-Stroband JB, Gosman MM, et al. Dissociation of lung function and airway inflammation in chronic obstructive pulmonary disease. Am J Respir Crit Care Med 2004; 170:499-504.

14 Pauwels RA, Löfdahl C-G, Laitinen LA, et al. Long-term treatment with inhaled budesonide in persons with mild chronic obstructive pulmonary disease who continue smoking. N Engl J Med 1999;340:1948-53.

15 Jeffery $\mathbf{P}$, Holgate S, Wenzel S. Methods for the assessment of endobronchial biopsies in clinical research: application to studies of pathogenesis and the effects of treatment. Am J Respir Crit Care Med 2003;168:S1-17.

16 KleinJan A, Vinke JG, Severijnen LW, et al. Local production and detection of (specific) lgE in nasal B-cells and plasma cells of allergic rhinitis patients. Eur Respir J 2000;15:491-7.

17 Sont JK, de Boer WI, van Schadewijk WA, et al. Fully automated assessment of inflammatory cell counts and cytokine expression in bronchial tissue. Am J Respir Crit Care Med 2003;167:1496-503.

18 Mullen JB, Wright JL, Wiggs BR, et al. Structure of central airways in current smokers and ex-smokers with and without mucus hypersecretion: relationship to lung function. Thorax 1987;42:843-8.

19 Rutgers SR, Postma DS, ten Hacken NH, et al. Ongoing airway inflammation in patients with COPD who do not currently smoke. Thorax 2000;55:12-8.
20 Wright JL, Lawson LM, Pare PD, et al. Morphology of peripheral airways in current smokers and ex-smokers. Am Rev Respir Dis 1983;127:474-7.

21 Fehrenbach H. Design-based counting. Am J Respir Crit Care Med 2004;169:1170-1

22 Zalacain R, Sobradillo V, Amilibia J, et al. Predisposing factors to bacterial colonization in chronic obstructive pulmonary disease. Eur Respir $J$ 1999; 13:343-8.

23 Soler N, Ewig S, Torres A, et al. Airway inflammation and bronchial microbial patterns in patients with stable chronic obstructive pulmonary disease. Eur Respir J 1999:14:1015-22.

24 Hill AT, Campbell EJ, Hill SL, et al. Association between airway bacterial load and markers of airway inflammation in patients with stable chronic bronchitis. Am J Med 2000; 109:288-95.

25 Retamales I, Elliott WM, Meshi B, et al. Amplification of inflammation in emphysema and its association with latent adenoviral infection. Am J Respir Crit Care Med 2001;164:469-73.

26 Shapiro SD. End-stage chronic obstructive pulmonary disease: the cigarette is burned out but inflammation rages on. Am J Respir Crit Care Med 2001:164:339-40.

27 Agusti A, MacNee W, Donaldson K, et al. Hypothesis: does COPD have an autoimmune component? Thorax 2003;58:832-4.

28 Cosio MG. Autoimmunity, T-cells and STAT-4 in the pathogenesis of chronic obstructive pulmonary disease. Eur Respir J 2004;24:3-5.

29 Hodge S, Hodge G, Holmes M, et al. Increased airway epithelial and T-cell apoptosis in COPD remains despite smoking cessation. Eur Respir J 2005;25:447-54

30 Dye JA, Adler KB. Effects of cigarette smoke on epithelial cells of the respiratory tract. Thorax 1994;49:825-34.

31 Wright JL, Churg A. Smoking cessation decreases the number of metaplastic secretory cells in the small airways of the Guinea pig. Inhal Toxicol 2002;14:1153-9.

32 van der Vaart H, Postma DS, Timens W, et al. Acute effects of cigarette smoke on inflammation and oxidative stress: a review. Thorax 2004:59:713-21.

33 Robbins CS, Dawe DE, Goncharova SI, et al. Cigarette smoke decreases pulmonary dendritic cells and impacts antiviral immune responsiveness. Am J Respir Cell Mol Biol 2004;30:202-11.

34 Gyllen P, Andersson BA, Qvarfordt I. Smokeless tobacco or nicotine replacement therapy has no effect on serum immunoglobulin levels. Respir Med 2004;98:108-14.

35 Soutar CA. Distribution of plasma cells and other cells containing immunoglobulin in the respiratory tract in chronic bronchitis. Thorax 1977;32:387-96.

36 Mili F, Flanders WD, Boring JR, et al. The associations of race, cigarette smoking, and smoking cessation to measures of the immune system in middleaged men. Clin Immunol Immunopathol 1991;59:187-200.

37 Möller GM, Vernooy JH, van Suylen RJ, et al. Increased expression of granzyme $\mathrm{A}$ in type II pneumocytes and lymphocytes of patients with severe COPD. Am J Respir Crit Care Med 2003;167:A72.

38 Hogan RJ, Usherwood EJ, Zhong W, et al. Activated antigen-specific $\mathrm{CD}^{+} \mathrm{T}$ cells persist in the lungs following recovery from respiratory virus infections. $J$ Immunol 2001:166:1813-22.

39 Mauad T, van Schadewijk A, Schrumpf J, et al. Lymphocytic inflammation in childhood bronchiolitis obliterans. Pediatr Pulmonol 2004;38:233-9.

40 Willemse BW, ten Hacken NH, Rutgers B, et al. Smoking cessation improves both direct and indirect airway hyperresponsiveness in COPD. Eur Respir 2004;24:391-6. 